\title{
Rainfall-triggered landslides, anthropogenic hazards, and mitigation strategies
}

\author{
M. C. Larsen \\ U.S. Geological Survey, 436 National Center, Reston, VA 20192, USA \\ Received: 15 July 2007 - Revised: 17 October 2007 - Accepted: 18 October 2007 - Published: 2 January 2008
}

\begin{abstract}
Rainfall-triggered landslides are part of a natural process of hillslope erosion that can result in catastrophic loss of life and extensive property damage in mountainous, densely populated areas. As global population expansion on or near steep hillslopes continues, the human and economic costs associated with landslides will increase. Landslide hazard mitigation strategies generally involve hazard assessment mapping, warning systems, control structures, and regional landslide planning and policy development. To be sustainable, hazard mitigation requires that management of natural resources is closely connected to local economic and social interests. A successful strategy is dependent on a combination of multi-disciplinary scientific and engineering approaches, and the political will to take action at the local community to national scale.
\end{abstract}

\section{Introduction: Nature made the storm, humans made the disaster}

"The term 'natural disaster' has become an increasingly anachronistic misnomer. In reality, human behavior transforms natural hazards into what should really be called unnatural disasters". United Nations Secretary General Kofi Annan (Annan, 1999)

Rainfall-triggered landslides are part of a natural process of hillslope erosion that can result in catastrophic loss of life and extensive property damage in mountainous, densely populated areas. In the United States, an average of 25 to 59 lives are lost each year, and annual property damage is estimated at $\$ 3.6$ billion, in 2001 dollars (Gori et al., 2003). Worldwide damage from natural disasters overall was estimated at $\$ 399$ to $\$ 479$ billion for the decade of the 1990s (Annan, 1999; O'Hare and Rivas, 2005). According to Haque and Burton

Correspondence to: M. C. Larsen

(mclarsen@usgs.gov)
(2005), the average annual damage costs had risen to $\$ 70$ billion by 2000. McBean and Henstra (2003) estimate that 80 percent of natural disasters are due to weather-associated hazards. As global population expansion on or near steep hillslopes continues, the human and economic costs associated with landslide disasters will increase.

Landslide hazard mitigation strategies generally involve hazard assessment mapping, warning systems, control structures, and regional landslide planning and policy development. Landslide hazard assessment mapping includes landslide inventory and susceptibility maps. Warning systems are usually based on networks of precipitation gages linked by radio- or satellite-telemetry to civil defense communication centers, and a broadcast communications system or network of warning sirens. Control structures are designed to stop, deflect or capture landslide debris before it reaches developed areas on or near hillslopes. Regional planning and policy development uses landslide susceptibility and risk maps to guide planners in the determination of where infrastructure can be safely located. Planners and policy makers also depend on hillslope stability modeling approaches that can be used to estimate when and where hillslopes are likely to fail (Carrasco et al, 2003; McBean and Henstra, 2003).

Sustainable hazard mitigation links management of natural resources with local economic and social resiliency (Mileti, 1999; NRC, 2006). Education of the general public is key to social resiliency. The objective, to increase fundamental understanding of landslide (and other) hazards may be best achieved by targeting school-age children (Ronan and Johnston, 2003). All of these strategies require multi-disciplinary scientific and engineering approaches, and the political will to take action at the local community to national scale. Unfortunately, landslide research efforts around the world are small relative to the economic costs of landslide damage, so the scientific and mitigation challenges are great (NRC, 2006; Keefer and Larsen 2007). The brief overview presented herein cites examples

Published by Copernicus Publications on behalf of the European Geosciences Union. 


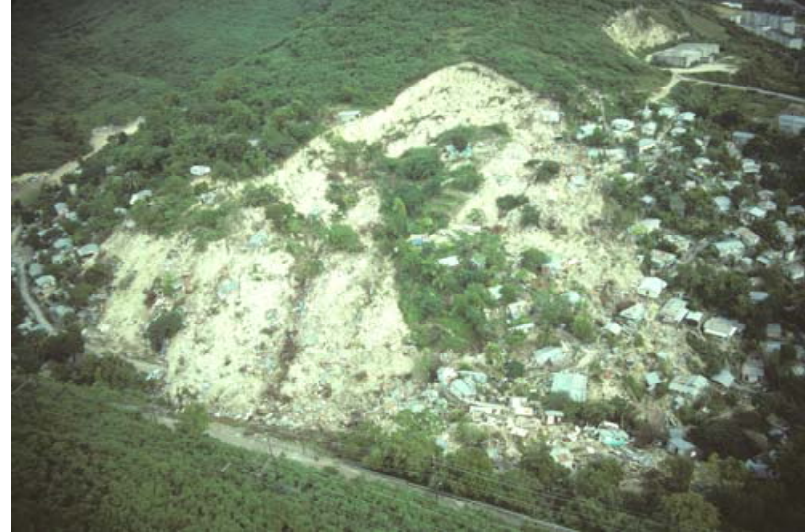

Fig. 1. Aerial view of Barrio Mameyes, Ponce, Puerto Rico, following October 7, 1985 landslide disaster (Jibson, 1989). Before the landslide, the area of exposed bedrock in the center of the photograph had a comparable density of small one-story houses as is seen on right side of photograph. (Photo from R. Jibson, USGS).

of rainfall-triggered landslide disasters in Puerto Rico and Venezuela where anthropogenic factors were significant, and discusses approaches for hazard mitigation.

\section{Rainfall-triggered landslides and anthropogenic haz- ards: examples from Puerto Rico and Venezuela}

\subsection{Puerto Rico}

On 7 October 1985, a rock-block slide in Barrio Mameyes, Ponce, Puerto Rico, killed an estimated 129 people (Jibson, 1989). Approximately 120 homes were destroyed and most victims were buried in hillslope debris; only 39 bodies were recovered (Fig. 1). In terms of loss of life, this was the worst single landslide disaster in the history of North America. This small community, located on the northwest side of Ponce, on Puerto Rico's south coast, was built on a steep hillslope overlying calcareous-sandstone bedrock. The hillslope failure was triggered between 3 and 4 am following heavy rainfall $(560 \mathrm{~mm}$ in $24 \mathrm{~h}$ ) associated with a tropical disturbance. The failure began with the sliding of 12-m-thick slabs of bedrock along bedding planes that were parallel to the hillslope surface (Jibson, 1989).

This community was particularly susceptible to landslide hazard because of a number of circumstances, including:

- The time of hillslope failure, when most residents were asleep.

- Self-built housing on a steep hillslope without planning or regulation.

- The use of septic tanks for sewerage and associated infiltration into hillslope soil.
- A leaking water-distribution pipeline at the top of the hillslope, which ruptured and emptied as much as 4 million liters of water onto the hillslope.

- The underlying bedrock configuration (bedding planes dipping parallel to the topographic slope).

A generalized landslide susceptibility map of Puerto Rico published by Monroe (1979) included Barrio Mameyes (and numerous other communities) in a large area of the island classified as having moderate susceptibility. As of 1985, however, no comprehensive education of island residents and officials regarding landslide hazards had been attempted. Furthermore, no landslide warning system, control structures or landslide-hazard policy existed in Puerto Rico in 1985.

\subsection{Venezuela}

Unusually heavy rainfall in December 1999 triggered thousands of debris flows and dozens of flash floods along a 300$\mathrm{km}$-long region of the north coast of Venezuela, resulting in an estimated death toll of 15,000 people (Larsen and Wieczorek, 2006). Most of the affected area was in the state of Vargas, population approximately 300000 . Vargas state was rapidly developed beginning in the 1970's, following construction of a multi-lane highway connecting the city of Caracas with the principal airport located on the coast. Because most Vargas residents had lived there for less than 30 years, local knowledge of debris-flow and flood hazard was limited (Larsen and Wieczorek, 2006).

Rainfall during early December 1999 was estimated at $1200 \mathrm{~mm}$, with $911 \mathrm{~mm}$ of this total recorded on 14-16 December. Floods and debris flows on 16 December affected numerous self-built, informal, as well as wealthy communities, many of which were constructed in highly vulnerable locations on alluvial fans and in narrow canyons, in the coastal state of Vargas (Fig. 2). This was one of the worst disasters recorded in the history of the Americas, resulting in the loss of life in Vargas state of approximately 5 percent of its population (Larsen and Wieczorek, 2006). The severity of the catastrophe can be attributed to multiple factors:

- A rare combination of meteorological conditions that resulted in almost double the mean annual rainfall over a period of weeks in December 1999.

- Extensive, poorly regulated development associated with a rapidly growing urban region (Caracas).

- Limited terrain acceptable for safe housing in this tectonically active setting at the base of a steep mountain range.

- Construction on geomorphologically active alluvial and debris fans and at river canyon mouths at the base of the mountain range. 
- As in the case in Puerto Rico, the most destructive debris flow activity occurred at night when many residents were sleeping.

No landslide susceptibility or hazard maps existed for Vargas in 1999, although Venezuelan scientists had long recognized and documented debris-flow hazard in the region (Audemard et al., 1988; Röhl, 1950; Schubert, 1985; Singer et al., 1983). Additionally, no landslide warning system existed nor were there any substantial debris-flow control structures in Vargas. Finally, no landslide hazard policy had been implemented in Vargas as of 1999.

\section{Mitigation strategies: what can be done?}

Mitigation has been defined as sustained, deliberate measures, implemented in advance, to avoid or reduce the impact of hazards and impending disasters (Haque and Burton, 2005). Landslide hazard mitigation generally involves landslide mapping, control structures, warning systems, and regional planning. Most effective approaches include a combination of these strategies, with good coordination between the scientific, engineering, and planning communities (Gori et al., 2003). Work cited by Gori et al. (2003) indicates that most land-use decision makers in the United States do not adequately address natural hazards issues. This issue is common in much of the developing world as well (O'Hare and Rivas, 2005). Communities can reduce their exposure to landslide hazard if they understand the threat, its potential impact, and their mitigation options (Spiker and Gori, 2000).

\subsection{Landslide maps and predictive models}

As summarized by the National Research Council (NRC, 2003), landslide maps include maps that depict hazard (potential for landslide occurrence), susceptibility (likelihood of landslide occurrence), vulnerability (extent of potential loss), and risk (probability of harmful consequences). The list should also include inventory maps - which delineate landslide locations from single or multiple triggering events (Wieczorek, 1984). Inventory maps are the basic data upon which the other maps are developed. The development of landslide maps can be less costly than warning systems and control structures, and the maps serve as important tools for planners and civil defense officials. However, landslide maps have inherent limitations because of local heterogeneities in hillslope geology, hydrology, land use/land cover, and other socioeconomic data used to develop the map, as well as change in some of these parameters following map publication.

Landslide and debris-flow modeling can enhance the utility of landslide hazard, susceptibility, and vulnerability maps. Examples of such models include: LAHARZ (Schilling, 1998; Iverson et al., 1998), SCOOPS (Reid et al., 2000); SHALSTAB (Dietrich et al., 2001), and TRIGRS
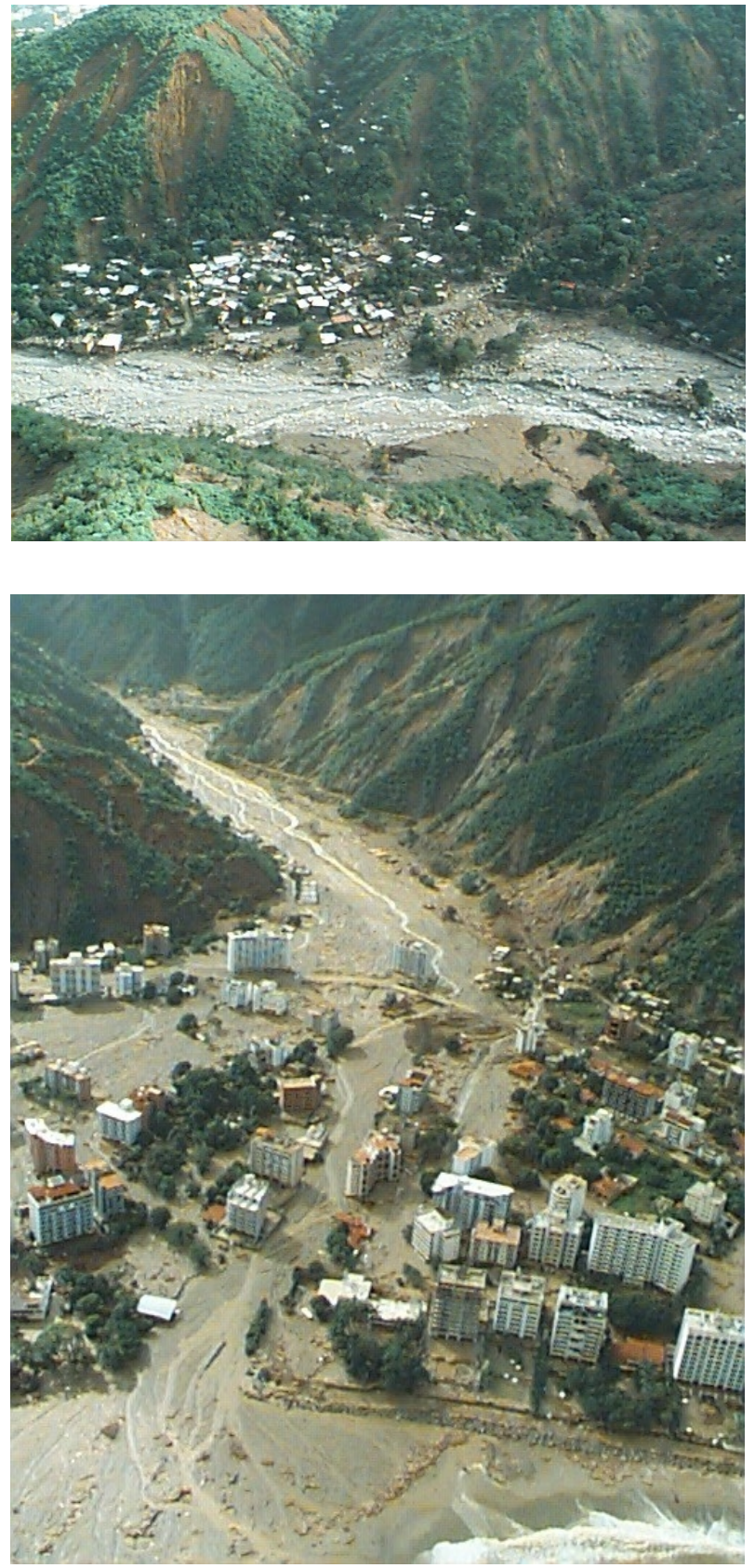

Fig. 2. Communities affected by debris flows and flash floods, Vargas state, Venezuela. A. Cluster of small houses on river flood plain at base of steep hillslope. Note debris-flow scars on hillslopes behind houses. B. Large apartment buildings on alluvial fan at mouth of a river draining the steep mountains of the Venezuelan north coast (Larsen and Wieczorek, 2006).

(Godt et al., 2006). Wilcock et al. (2003) provide insightful examples of the use of some of these and other models. They discuss the challenges that scientists and managers face in assessing, estimating, and communicating hazard and uncertainty. 


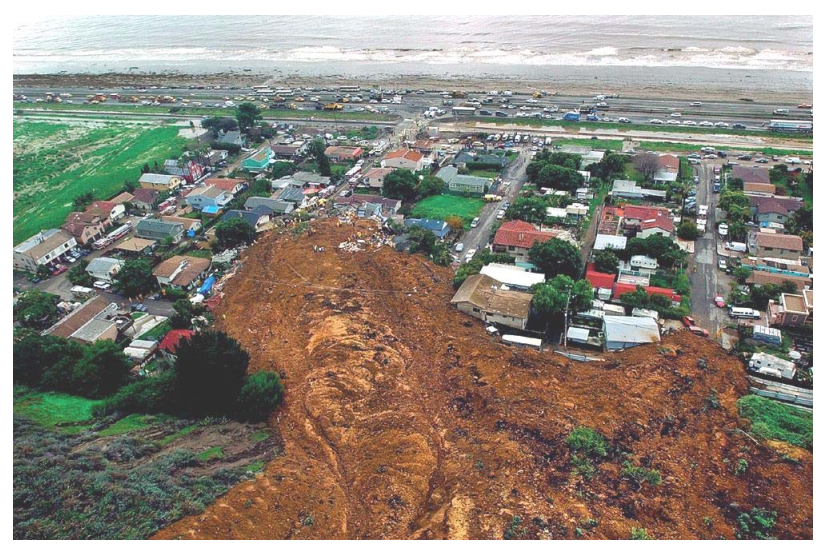

Fig. 3. Landslide at La Conchita, Ventura, California, on 10 January 2005, destroyed 13 houses, severely damaged 23 others, and killed 10 people (Jibson, 2005).

Models help scientists address the complexity of landslide occurrence and behavior, for example at La Conchita in Ventura, California (Fig. 3). In 1995, a landslide consisting of a relatively coherent block of earth at La Conchita caused property damage but no fatalities. Ten years later, another landslide remobilized from the 1995 deposit, transformed rapidly into a highly fluid debris flow, and traveled downslope at a speed of 5 to $10 \mathrm{~m} \mathrm{~s}^{-1}$, causing 10 fatalities (Jibson, 2005). Landslide models can serve as useful tools for officials charged with public safety, by allowing the officials to estimate the changes in slope stability that might occur under varying rainfall, land use, and other scenarios. The models use a combination of geologic, topographic, hydrologic, geotechnical, and land use/land cover factors to estimate the probability of hillslope failure. Scientists use locally- to regionally-derived data to calibrate the landslide models, which are then used to predict where, and under what conditions, landslides are likely to occur.

\subsection{Landslide warning systems}

Landslide warning systems provide a rapid means to monitor and communicate hazard information to vulnerable communities. Warning (and monitoring) systems are used mainly to protect lives, by indicating that landslides are likely to occur and providing time for notification and evacuation of vulnerable populations. These systems, however, do not substantially reduce property damage (NRC, 2003). Futhermore, despite their widespread occurrence and potentially deadly nature, it remains difficult to predict precisely when and where landslides are likely to occur, mainly because of hillslope heterogeneity attributable to the factors listed above for landslide models (Keefer and Larsen, 2007).

Warning systems require three basic components: 1) rainfall sensors and telemetry, 2) a rainfall threshold model, which is used by scientists to inform civil defense authori- ties when rainfall conditions equal or approach those rainfall amounts that have triggered landslides in the past, and 3) a means for communicating the warning to the public (Caine, 1980; Keefer et al., 1987; Ellen et al., 1989; Larsen and Simon, 1993; Giannecchini, 2005; Cavallo and Giannoni, 2006).

To be effective, a landslide warning system must have an extensive array of rainfall sensors that report in real time, should be based on a robust rainfall-threshold model, and have rapid, efficient links between authorities and residents. An example of some of the scientific and logistical challenges and successes associated with a landslide warning system used in the San Francisco Bay area in the 1980's and 1990's is described in Wilcock et al. (2003). A detailed description of the warning system was published by Keefer et al. (1987). Other landslide warning systems have been developed for Honolulu, Hawaii, and China (Wilson et al., 1992; Zhou et al., 2002). Landslide warning systems, particularly rainfall sensor arrays, are expensive to develop, install, maintain, and operate, and can be problematic during severe weather when they are most needed. Furthermore, warning systems in steeply sloping areas such as the locations described above, for Puerto Rico and Venezuela, may not give enough time to evacuate large or dispersed communities. Additionally, operators of warning systems face a trade off between their role in the protection of life, and the social and economic costs of false alarms (Wilcock et al., 2003). Credibility for a system can be substantially compromised by false alarms. The frequency of false alarms can be reduced if the conservative strategy of giving generalized warnings ahead of a storm is adopted; however, the use and value of a warning is inversely proportional to the size of the geographic area included in the warning.

\subsection{Control structures}

In areas with high landslide hazard where population is dense or where property value is great, engineering solutions such as sabo dams, retention walls, and debris-flow catchment basins have been used to protect lives and property (Ikeya, 1989; VanDine, 1996; Chan, 2000) A sabo dam is a small, low-head dam used on ephemeral or perennial stream channels to capture or slow the velocity of debris-flow material. Retention walls stop, deflect or capture landslide debris before it reaches developed areas on or near a hillslope. They are most commonly used at the hillslope base to protect expensive or critical infrastructure (Turner and Schuster, 1996). Large debris-flow catchment basins are used, for example, in the Los Angeles, California region where debris flows are common and property values are high (Turner and Schuster, 1996). Engineering works such as these can be effective and are politically appealing because they demonstrate concrete action by governmental authorities, but are expensive, require regular maintenance (e.g. removal of accumulated sediment and debris), are a highly local solution, and 
may be overwhelmed during large storms. Additionally, control structures may lead to greater vulnerability by fostering new or additional development in or close to hazardous areas (Mileti, 1999).

Some relatively inexpensive solutions include orienting roads to serve as corridors for debris flows, using large multistory buildings to serve as barriers, and orienting buildings so that their footprint diminishes damage, for example orienting the long dimension parallel to the direction of flow, thereby minimizing the width of the building exposed to a debris flow (Hungr et al., 1987). Furthermore, large buildings can also serve as refuges, as was the case for many residents in Vargas, Venezuela (Larsen and Wieczorek, 2006).

\subsection{Regional planning and policy development}

Effective regional planning includes the identification of potentially hazardous areas, the mitigation steps described above, and the development of policies and regulation to guide development in order to reduce risk (Gori et al., 2003). The planning and decision making is most likely to succeed if it includes federal, state and local government, as well as nongovernmental and community organizations (NRC, 2003).

Regional planning and policy development is based on the landslide hazard mitigation strategies described above: landslide map, model, warning system, and control structure development, all of which require extensive field work by geologists, hydrologists, and engineers. The calibration of model and map parameters requires that scientists document evidence of past landslide occurrence and estimate future probability. Maps must be easy to interpret and produced at a scale useful to citizens, managers, and planners. Finally, although the development of landslide maps can be cost effective, implementation requires technical expertise, extensive education of users and the public - including good communication between scientist and policy makers, and ultimately, strong political will. It is essential that local engineers, scientists and civil defense officials are jointly involved in the process of hazard assessment and mitigation. Ultimately, sustained communication with, and education of local citizens is necessary for implementation to be successful. Social, political, and cultural acceptance resulting from an interactive, participatory process involving local communities may produce the best outcomes with respect to mitigation, preparedness, and recovery (Haque and Burton, 2005; NRC, 2006).

\section{Conclusions}

Landslide hazard can be mitigated with combinations of susceptibility and hazard maps, warning systems, control structures, and the development of effective planning and policy. Communities at risk must be evaluated to determine which element or combination of approaches is most appropriate.
Highly technical solutions may not be appropriate in many parts of the world and community based actions may be the most effective approach, including their close participation in vulnerability reduction through the planning process (O'Hare and Rivas, 2005). Some simple structural controls are effective and can be relatively inexpensive if considered during the design and planning process: i.e. orientation of buildings (to serve as barriers or to minimize their exposure footprint) and streets (to serve as conduits for debris flow material). Robust warning systems are useful but must be stable, based on strong science, and well calibrated. Warning system operators must effectively balance the need to protect life while minimizing false alarms. Landslide susceptibility and hazard maps, in concert with predictive modeling and planning can be relatively inexpensive and can reduce the loss of life and property, but they require political will for sustained implementation. Education about natural hazards is critical for individuals to successfully prepare, must be ongoing, and may be most effective when aimed at school-age children (Ronan and Johnston, 2003; NRC, 2006). Strong leadership from state and federal governments can foster planning that leads to sustainable hazard mitigation and development (Mileti, 1999). The political challenge for leaders derives from the fact that the costs of hazard mitigation are paid in the present, while the benefits occur in the future, and are intangible because they are the disasters that do not happen (Annan, 1999). Finally, real hazard mitigation requires resolution of poverty and population pressures, as more than 90 percent of all disaster victims worldwide are in developing countries (Annan, 1999).

Acknowledgements. This work was supported by the U.S. Geological Survey Hydrologic Research and Development Program. Insightful review comments provided by Bruce D. Malamud, Kings College, London, and Paula L. Gori, U.S. Geological Survey, greatly improved the manuscript.

Edited by: P. Fabian

Reviewed by: B. Malamud and P. Fabian

\section{References}

Annan, K.: Facing the humanitarian challenge: towards a culture of prevention, Intro. to the Secretary-General's Annual Report on the Work of the Organization, September, 1999, http://www. unis.unvienna.org/unis/pressrels/1999/sg2358.html, accessed on 6 July 2007.

Audemard, F. A., De Santis, F., Montes, L., Lugo, M., and Singer, A.: El alud torrencial del 6-9-1987 del Río Limón, al norte de Maracay, Estado Aragua, Informe Interno FUNVISIS (Fundación Venezolana de Investigaciones Sísmicas), Caracas, Venezuela, 9 pp., 1988.

Caine, N.: The rainfall intensityduration control of shallow landslides and debris flows, Geografiska Annaler, 62A, 23-27, 1980.

Carrasco, R. M., Pedraza, J., Martin-Duque, J. F., Mattera, M., Sanz, M. A., and Bodoque, J. M.: Hazard zoning for landslides 
connected to torrential floods in the Jerte Valley (Spain) by using GIS techniques, Nat. Hazards, 30, 361-381, 2003.

Cavallo, A. and Giannoni, F.: Natural risk warning: comparison of two methodologies, Adv. Geosci., 2, 335-338, 2006, http://www.adv-geosci.net/2/335/2006/.

Chan, R. K. S.: Hong Kong slope safety management system, Proc. of the Symposium on Slope Hazards and their Prevention, Jockey Club Research and Information Centre for Landslip Prevention and Land Development, University of Hong Kong, 1-16, 2000.

Dietrich, W. E., Bellugi, D., de Asua, R. R.: Validation of the shallow landslide model, SHALSTAB, for forest management, Land use and watersheds: human influence on hydrology and geomorphology in urban and forest areas, Water Sci. Appl., 2, 195-227, 2001.

Ellen, S. D., Algus, M. A., Cannon, S. H., Fleming, R. W., Lahr, P. C., Peterson, D. M., and Reneau, S. L.: Description and mechanics of soil slip/debris flows in the storm, Landslides, floods, and marine effects of the storm of January 3-5, 1982, in the San Francisco Bay region, California, in: U.S. Geol. Surv. Professional Paper, edited by: Ellen, S. D. and Wieczorek, G. F., 1434, 63-112, 1989.

Giannecchini, R.: Rainfall triggering soil slips in the southern Apuan Alps (Tuscany, Italy), Adv. Geosci., 2, 21-24, 2005, http://www.adv-geosci.net/2/21/2005/.

Godt, J. W., Baum, R. L, Lu, N., Savage, W. Z., and McKenna, J. P.: Applying distributed, doupled hydrological slope-stability models for landslide hazard assessments, Eos Trans. AGU, 87(52), Fall Meet, Suppl., Abstr., H54B-06, 2006.

Gori, P. L., Jeer, S. P., and Highland, L. M.: Enlisting the support of land-use planners to reduce debris-flow hazards in the United States, in: Debris-flow hazards mitigation: Mechanics, Prediction and Assessment, edited by: Rickenmann, D. and Chen, C., Millpress, Rotterdam, 1119-1127, 2003.

Haque, C. E. and Burton, I.: Adaptation options strategies for hazards and vulnerability mitigation: an international perspective, Mitigation and Adaptation Strategies for Global Change, 10, 3, 335-353, 2005.

Iverson, R. M., Schilling, S. P., and Vallance, J. W.: Objective delineation of lahar-inundation hazard zones, Geol. Soc. Am. Bull., 110, 972-984, 1998.

Jibson, R. W.: Debris flows in southern Puerto Rico, Geol. Soc. Am., Special paper 236, 29-55, 1989.

Jibson, R. W.: Landslide hazards at La Conchita, California, U.S. Geol. Surv. Open-File Rep. 2005-1067, 12 pp., 2005.

Ikeya, H.: Debris flow and its countermeasures in Japan, Journal Bulletin of Engineering Geology and the Environment, 40, 1533, 1989.

Keefer, D. K., Wilson, R. C., Mark, R. K., Brabb, E. E., Brown, W. M.., Ellen, S. D., Harp, E. L., Wieczorek, G. F., Alger, C. S., and Zatkin, R. S.: Realtime landslide warning during heavy rainfall, Science, 238, 921-925, 1987.

Keefer, D. K. and Larsen, M. C.: Assessing Landslide Hazards, Science, 316, 1136-1138, 2007.

Larsen, M. C. and Simon, A.: Rainfall-threshold conditions for landslides in a humid-tropical system, Puerto Rico, Geografiska Annaler, 75A(1-2), 13-23, 1993.

Larsen, M. C. and Wieczorek, G. F.: Geomorphic effects of large debris flows and flash floods, northern Venezuela, 1999: tropical geomorphology with special reference to South America, in:
Zeitschrift für Geomorphologie Suppl., edited by: Latrubesse, E., 145, 147-175, 2006.

McBean, G. and Henstra, D.,Dan Henstra: Climate change, natural hazards and cities, Natural Resources Canada, ICLR Research, Paper Series, No. 31, 18 pp., 2003.

Mileti, D. S.: Disasters by design: a reassessment of natural hazards in the United States, Joseph Henry Press, Environmental Studies, 351 pp., 1999.

Monroe, W. H.: Map showing landslides and areas of susceptibility to landsliding in Puerto Rico, U.S. Geological Survey Miscellaneous Investigations Series Map I-1148, 1 sheet, 1:240 000 scale, 1979.

NRC (National Research Council): Partnerships for reducing landslide risk: assessment of the national landslide hazards mitigation strategy, National Research Council of the National Academies, The National Academies Press, Washington, D.C., 144 pp., 2003.

NRC (National Research Council): Facing hazards and disasters: understanding human dimensions, committee on disaster research in the social sciences: future challenges and opportunities. National Research Council of the National Academies, The National Academies Press, Washington, D.C., 408 pp., 2006.

O'Hare, G. and Rivas, S.: The landslide hazard and human vulnerability in La Paz City, Bolivia, The Geographical Journal, 171(3), 239-258, 2005.

Reid, M. E., Christian, S. B., and Brien D. L.: Gravitational stability of three-dimensional stratovolcano edifices, J. Geophys. Res., 105(B3), 6043-6056, 2000.

Röhl, E.: Los diluvios en las montañas de la cordillera de la costa, Boletín de la Academia de Ciencias Físicas, Matemáticas y Naturales, Venezuela, 38, 1-28, 1950.

Ronan, K. R. and Johnston, D. M.: Hazards education for youth: a quasi-experimental investigation, Risk Anal., 23, 1009-1020, 2003.

Schilling, S. P.: LAHARZ GIS programs for automated mapping of Lahar-inundation hazard zones, U.S. Geol. Surv. Open-File Report 98-638, 1998.

Schubert, C.: Aluviones colgantes en la cordillera de la costa: indicio de aridez durante el quaternario tardio, Acta Científica Venezolana, 36, 201-202, 1985.

Singer, A, Rojas, C., and Lugo, M.: Inventario nacional de riesgos geológicos, mapa, glosario y comentarios, Serie Técnica FUNVISIS, (Fundación Venezolana de Investigaciones Sísmicas), 0383, 126, 1983.

Spiker E. C. and Gori, P L.: National landslide hazards mitigation strategy - framework for loss reduction, U.S. Geol. Surv. Circular 1244, 64 pp., 2000.

Turner, A. K. and Schuster, R. L (Eds.): Landslides, investigation and mitigation: Special Report 247, Transportation Research Board, National Academy Press, Washington, D.C., 3675, 1996.

VanDine, D. F.: Debris flow control structures for engineering, British Columbia Ministry of Program, Working Paper 22, 68 pp., 1996.

Wieczorek, G. F.: Preparing a detailed landslide inventory map for hazard evaluation and reduction, Bulletin of the Association of Engineering Geologists, 21, 337-342, 1984.

Wilcock, P. R., Schmidt, J. C., Wolman, M. G., Dietrich, W. E., Dominick, D. W., Doyle, M. W., Gordon, E. G., Iverson, R. M., 
Montgomery, D. R., Pierson, T. C., Schilling, S. P., and Wilson, R. C.: When models meet managers: examples from geomorphology, in: American Geophysical Union Monogragh Series, edited by: Wilcock, P. R. and Iverson, R. M., 135, 27-40, 2003.

Wilson, R. C., Torikai, J. D., and Ellen, S. D.: Development of rainfall warning thresholds for debris flows in the Honolulu district, Oahu, U.S. Geol. Surv. Openfile report 92-521, 45 p, 1992.
Zhou, J., Wang, L., Xie, B.: A study on the early-warning technique concerning debris flow disasters, Journal of Geographical Sciences (Science Press Beijing), 12, 363-370, 2002. 